\title{
Qualitative geophysical interpretation of the Sudbury Structure
}

\author{
Oladele Olaniyan ${ }^{1}$, Richard S. Smith ${ }^{1}$, and Bill Morris ${ }^{2}$
}

\begin{abstract}
The Sudbury Structure is one of the most studied geologic structures in the world due to its enigmatic nature and mineral wealth. The available geologic work from the literature and mining industry operations accumulated for more than a century was recently assessed and compiled into a bedrock geologic map. Most regional geophysical investigations of the Sudbury Structure have been quantitative - modeling and depth estimation without a clear definition of surface control. Airborne total magnetic intensity data over the Sudbury Structure were compiled, processed, and interpreted, to define magnetic stratigraphy boundaries and near-surface lineaments. Traditional directional and normalized derivatives were computed to enhance the high-frequency information in the magnetic field. Available airborne frequency-domain electromagnetic (EM) data were also interactively interpreted along profiles and in a gridded format to isolate conductive structures. On-screen geographic information system-based information extraction from multiple derivatives was used to interpret the magnetic contacts, dykes, and lineaments. The magnetic interpretation was compared with published bedrock maps of the Sudbury Structure. Magnetic contacts based on the qualitative classification of the magnetic texture did not always correspond to the geologic boundaries on the existing maps. Some magnetic lineaments corresponded with well-defined geologic structures, some were further extensions of partially mapped structures, and others are newly identified linear structures. Conductive locations identified from the EM profiles were probably due to responses from conductive ore bodies, faults, dykes, lithological contacts, and cultural objects.
\end{abstract}

\section{Introduction}

Genesis of the current morphology of the Sudbury Structure involved several geologic events: (1) a large-scale meteorite impact event generated a thick melt body overlain by a breccia complex (Dietz, 1964; French, 1972), (2) turbidite sediment infill of the crater basin or Penokean foreland basin, and (3) deformation of an originally circular crater to its current elliptical shape. Although the age of the impact event has been well established by radiometric age dating $(1849 \pm 3.4 \mathrm{Ma}$, Krogh et al., 1984), the timing and spatial extent of the sedimentation and the deformation events continue to be the subject of ongoing discussion. Critical to achieving a better understanding of the evolution of the Sudbury Structure is having a geologic map that is capable of revealing details about the stratigraphic relationships between individual lithological units and the disposition, displacement and distribution of faults and folds that modified the original structure.

Geologic maps of the Sudbury Structure were first published in the late 1880s (Bell, 1891; Giblin, 1984). Over the following $100+$ years, revised geologic maps at varying scales have been published by many authors
(Burrows and Rickaby, 1930; Collins, 1937). Mining companies active in the Sudbury area were also producing detailed studies of their individual mineral deposits (e.g., Lochhead, 1955). Compilation maps that summarized the geology of the Sudbury area began to appear with the work of Card (1978). These were followed by a detailed basin study by Dressler (1984). Following publication of the 1984 Ontario Geological Survey volume 1 , there was a dramatic increase in the number of geologic studies of the Sudbury Structure. The culmination of these studies was the publication of the 2005 bedrock geology compilation map reported by Ames et al. (2005) (Figure 1).

The earliest geologic maps of the Sudbury Basin were constructed purely on discrete and sparse field observations. As in many other areas of the Canadian Shield, outcrops are limited (less than 1\% outcrop in some areas) and access is difficult. Compounding the problem was the need to render these maps in a coherent reference frame because over the years poorly constrained air photograph mosaics have been used as a base for field mapping projects. It must be noted that it is only within the last 20 or so years that global

\footnotetext{
${ }^{1}$ Laurentian University, Department of Earth Sciences, Sudbury, Ontario, Canada. E-mail: ox_olaniyan@laurentian.ca; rssmith@laurentian.ca

${ }^{2}$ McMaster University, School of Geography and Earth Sciences, Applied Geophysics Group, Hamilton, Ontario, Canada. E-mail: morriswa@ mcmaster.ca.

Manuscript received by the Editor 13 November 2012; revised manuscript received 9 January 2013; published online 26 July 2013 . This paper appears in Interpretation, Vol. 1, No. 1 (August 2013); p. T25-T43, 13 FIGS., 2 TABLES.

http://dx.doi.org/10.1190/INT-2012-0010.1. @ 2013 Society of Exploration Geophysicists and American Association of Petroleum Geologists. All rights reserved.
} 
positioning system sensors have been used to provide locational information at decimeter scales in globally defined projection and datum reference frames. Yet even with high-resolution locational information, the field geologist is still faced with the problem of having to decide how to link observations between isolated outcrops.

Airborne geophysical data acquisition and satellite imagery have provided the overview information that permits field geologists to link outcrop information through the continuity of a characteristic geophysical, or spectral signature. Recent advances in data acquisition systems have increased the sensitivity and spatial resolution of remote sensing platforms; it is now possible to perceive features that a few years back were undetectable. For example, at the time that Dressler (1984) produced his compilation map of the Sudbury Structure, the best resolution aeromagnetic data available were based on 800-m flight line spacing.

In addition to advances in instrumentation, there have also been great improvements in data processing packages, which in turn have led to changes in map production. Geophysical data processing with embedded edge detection routines allows the interpreter to quickly locate bounds of regions with a similar geophysical response. Introduction of geographical information system (GIS) protocols permits the user to rapidly integrate responses from multiple sensor packages and to interrogate individual data sources for locational constraints. In this context, it is worth noting that the recent Ames et al. (2005) compilation is available as Environmental Systems Research Institute (ESRI) ArcGIS shapefiles, whereas the Dressler (1984) map was original only available as a print copy.

It is not clear what geophysical data was used in the Ames et al. (2005) compilation map. However, it is known that since that map was published, more highresolution geophysical imagery of the Sudbury Structure has become publicly available. The authors of the present study are of the opinion that a qualitative geophysical interpretation of magnetic contacts, lineaments, and discontinuities based on magnetic mineral distribution will provide better surface control for a subsequent quantitative study. The aim of this project is to process, interpret, and integrate the available aeromagnetic and electromagnetic (EM) data of the Sudbury Structure, to (1) extract contact information, (2) define a magnetostratigraphy based on the distribution of the magnetic anomaly amplitudes and textures, (3) delineate magnetic lineaments (faults), and (4) identify locations of conductive bodies. This interpretation provides a viable geophysics-based map of the bedrock geologic contacts and fault distribution within the Sudbury Structure. Modifications suggested in the new geophysical interpretation map are discussed through comparison with the currently accepted geologic map, which was constructed from geologic outcrops, and an older poorer resolution magnetic anomaly map.

\section{Geology of the sudbury structure}

The Sudbury Structure (Giblin, 1984) is typically considered to have been initiated by a meteorite impact at $\sim 1850 \mathrm{Ma}$ (Krogh et al., 1984). It lies regionally at a continental margin, developed adjacent to the Archean Superior Province, with Paleoproterozoic metasediments of the Southern Province occurring to the south. Lithologies associated with the Sudbury Structure include a basal Archean high-grade metamorphic terrain and weakly metamorphosed late Precambrian diabase dikes. When discussing the geology of the Sudbury Structure, it is common practice to subdivide the outcrop pattern into three areas: the North Range the elliptical curved northern edge that is mostly dipping to the south, the South Range - the less elliptical southern edge that is dipping vertically to slightly overturned to the south, and the East Range - the arcuate eastern end of the basin that links the North and South Ranges.

The oldest rocks in the Sudbury region form the footwall to the Sudbury Igneous Complex (SIC) on the North and East Ranges. Archean rocks of the Levack Gneiss Complex, which include high metamorphic grade, granitoids, metavolcanics, and metasediments, were uplifted in advance of the meteorite impact event (2711 Ma, Krogh et al., 1984; Milkereit et al., 1992). On the South Range, Archean-age rocks are restricted to the Creighton and Murray granitic plutons. Sitting unconformably above the Archean is a thick metasedimentary sequence of the Huronian Supergroup ( $>2450$ to $2200 \mathrm{Ma}$, Krogh et al., 1996; Young et al., 2001), which defines the Southern Province. Locally on the South Range, the contact of the Huronian Supergroup and the SIC is marked by mafic and felsic volcanic rocks (Peredery and Morrison, 1984).

Internally, the Sudbury Structure includes two lithological sequences: (1) rocks directly related to the Sudbury Impact event, such as the SIC, Sudbury breccia, and offset dykes and (2) rocks, such as sediments and dikes, that were emplaced at a later time (Figure 1).

The SIC is a $28-\times 58-\mathrm{km}$ elliptical collar of layered igneous rocks that encloses the Sudbury basin. This includes a unit known as the main mass that contains the economically important contact Sublayer (Naldrett et al., 1984). The main mass of the SIC consists of hypersthene-bearing norite at the base, a transition zone of quartz gabbro, and the uppermost granophyre unit (Naldrett, 1984). Xenolith and Ni-Cu-PGE ore bearing gabbronoritic rocks of the Sublayer unit occur as sheets and lenses between the main mass norite and the outermost footwall rocks (Naldrett et al., 1984).

Dykes and irregular bodies of Sudbury breccia, with subrounded clasts in an aphanitic textured matrix, occur from the outermost contact of the SIC, to up to $80 \mathrm{~km}$ into the footwall of the SIC (Peredery and Morrison, 1984). The offset dykes are sulfide-bearing radial and concentric quartz diorite offset dykes that either radiate from the SIC at an angle or are subparallel to the SIC (Grant and Bite, 1984). 
The sedimentary basin is filled with hypabyssal intrusions, overlain by pelagic mudrocks and proximal turbidite sedimentary rocks of the Whitewater group. The Whitewater group is $2900 \mathrm{~m}$ thick and made up of four formations. At the base of the group is a hypabyssal intrusion and an upward-fining complex sequence of breccia (the Onaping Formation), which is in places overlain by a sulfide-rich carbonate (the Vermilion Formation), a pyritic and carbonaceous laminated mudstone (Onwatin Formation), and finally the muddy sandstone of the Chelmsford Formation (French, 1972; Ames et al., 1998).

Subsequent to crater formation, it is generally thought that deformation of the Sudbury Structure occurred during two separate prolonged episodes of ductile and brittle deformation: the Penokean orogeny (1900-1700 Ma, Deutsch et al., 1995; Riller, 2005) and the Grenville orogeny (1000 Ma, Zolnai et al., 1984). Unfortunately, the geologic record of the Sudbury Structure contains few rocks that were formed between

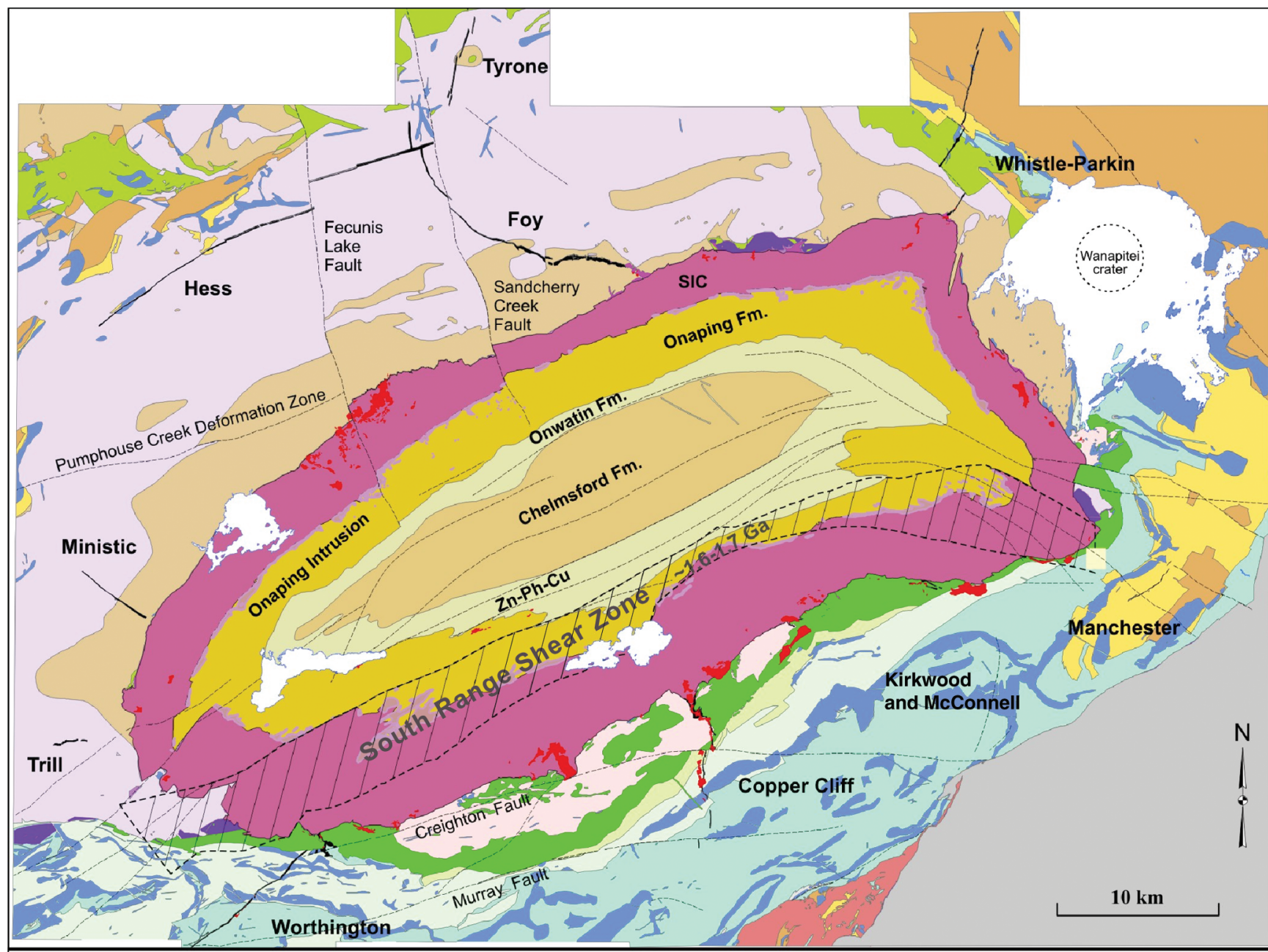

D


the $1850 \mathrm{Ma}$ SIC and the $1238 \mathrm{Ma}$ Sudbury olivine diabase dikes, so the timing of the deformation remains somewhat speculative. Recently, Tschirhart and Morris (2012) show that the Grenville orogeny only resulted in a broad-scale fault segmentation of the basin. Further geochronological data reported by Bailey et al. (2004) have suggested that the basin was also deformed during a Mazatzal-age event (1700-1600 Ma). This interpretation is in agreement with seismic (Wu et al., 1995) and paleomagnetic evidence (Morris, 2002), that have both indicated two distinct periods of deformation, both of which occurred prior to the late Grenvillian event.

Furthermore, extensive deformation has resulted in a series of faulting, folding, fracturing, and shearing of rocks within the Sudbury Structure (Rousell, 1975). The faults within the Sudbury Structure have been grouped into sets based on their geographic location and strike (Rousell et al., 2002). The fault sets include the Murray set $\left(77^{\circ}\right.$ strike, Card, 1978), the Vermilion set $\left(065^{\circ}\right.$ strike, Thompson, 1957), the Fecunis set $\left(346^{\circ}\right.$, Cochrane, 1991), the Norduna set $\left(300^{\circ}\right.$, Dressler et al., 1991), and the Errington set (034 ${ }^{\circ}$, Paakki, 1992).

Weak zones in the Sudbury rocks, such as faults and fractures resulting from the brittle deformation and contacts of the rock units, have been intruded by a series of dykes of different composition and age. These dykes include (1) the northwest-trending Matachewan mafic dykes (2.5 Ga, Heaman, 1997), (2) Nipissing diabase dykes (2219 Ma, Corfu and Andrews, 1986), which intruded the Huronian supergroup and occur as undulating sills and dykes, conforming dykes, lopolith, and

Table 1. Description of airborne geophysical data sets used.

\begin{tabular}{|c|c|c|c|c|c|}
\hline S/No & Data type & Flight height & Flight line spacing & Cell size & Data provided courtesy of \\
\hline 1 & Magnetic & $43 \mathrm{~m}$ & $100 \mathrm{~m}$ & $20 \mathrm{~m}$ & Xstrata \\
\hline 3 & Magnetic & Variable & Variable & $10 \mathrm{~m}$ & Wallbridge Mining \\
\hline 4 & Frequency EM & $30 \mathrm{~m}$ & $100 \mathrm{~m}$ & $20 \mathrm{~m}$ & Xstrata \\
\hline
\end{tabular}

\section{Vertical Derivative Map of the TMI ( Before and After Microleveling)}

a)

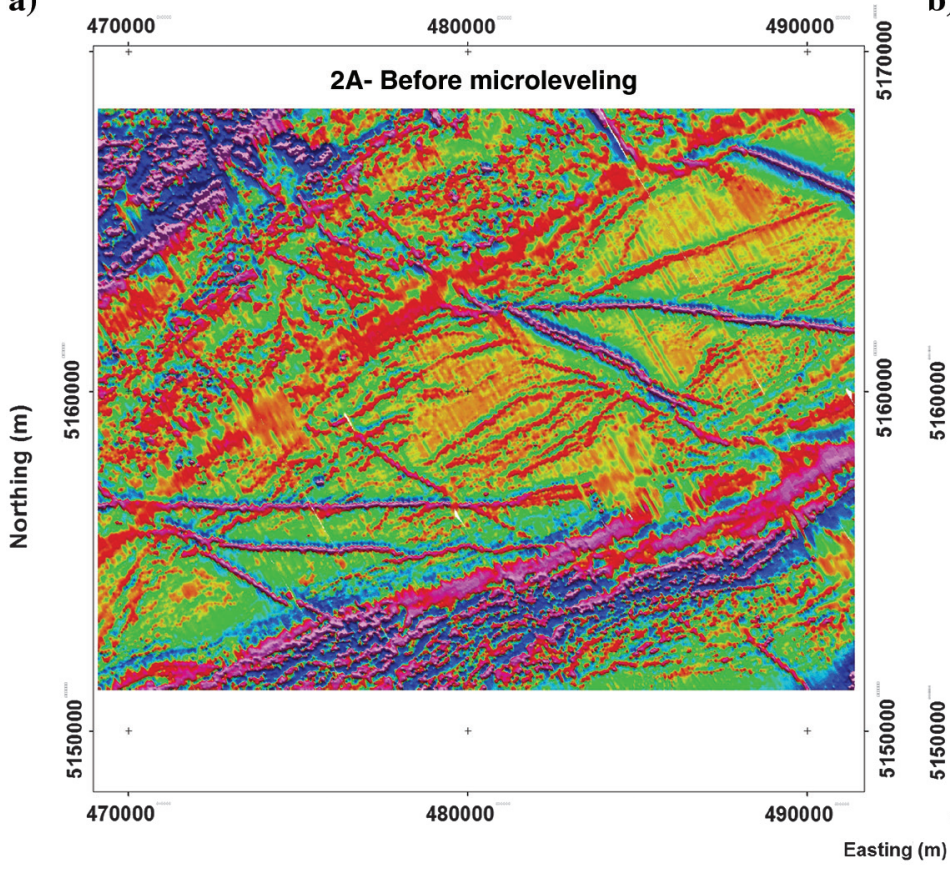

a)

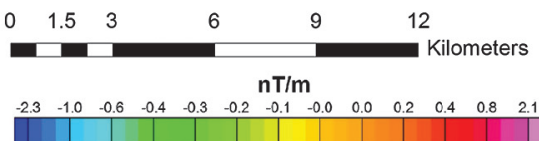

Figure 2. (a) First VDR of the TMI before microleveling. Geophysical acquisition noise features trend in the northwest direction along the flight line. (b) First VDR of the TMI after microleveling. b)

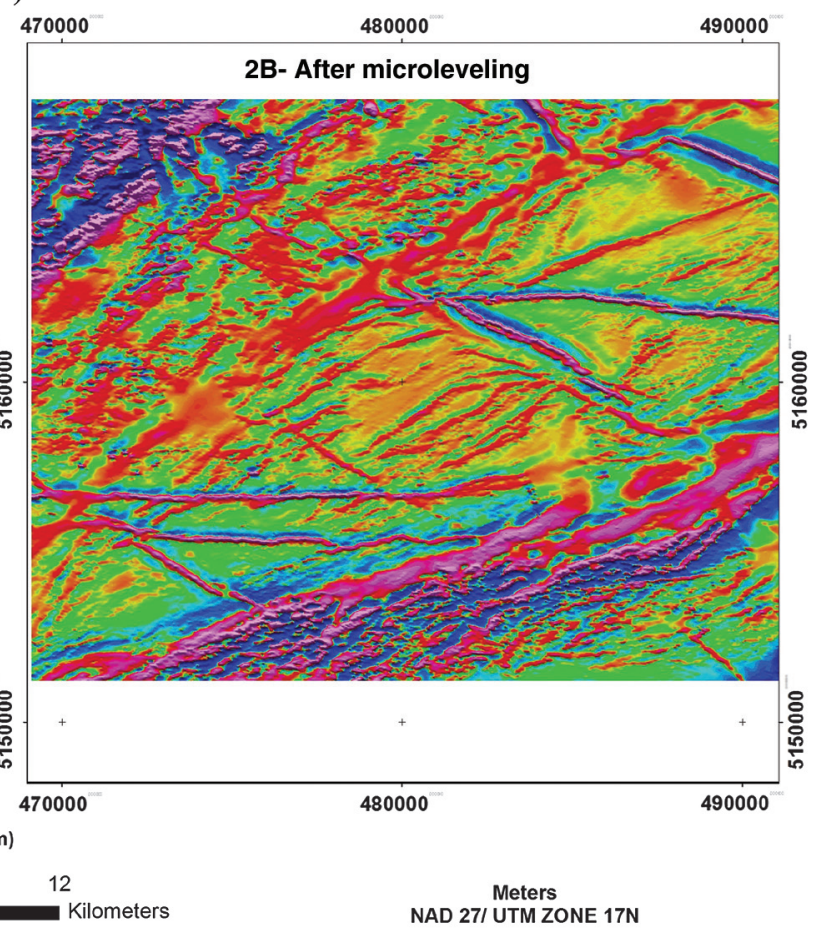

NAD 27 I UTM ZONE 17N 
stocks, (3) Biscotasing dykes (2167 Ma, Buchan et al., 1993), (4) Post-SIC northwest-trending hornblende diabase dykes associated with the Murray fault set (trap dykes) (Cochrane, 1991), and (5), olivine diabase dykes (1238 Ma, Fahrig and West, 1986), intruded after the Sudbury event, that have been faulted and rotated about an axis perpendicular to the northeast faults during the Grenville orogeny (1000 Ma, Zolnai et al., 1984; Tschirhart and Morris, 2012).

Geophysical maps reveal contacts and lineaments. All geophysical sensors integrate signals in proximity of the sensor; some of these geologic lineaments occur and are mappable on the surface, whereas some are buried at depth, especially within the Whitewater Series, or they are under lakes, making it difficult for a geologist to fully define their location. One major advantage of airborne geophysical data sets is that they provide a synoptic view of the in situ structures and contacts at varying depths. Although the distribution of silicate and magnetic minerals are often not the same, qualitative interpretation of geophysical data sets can provide good ground control for a geologist, especially in accessible and rugged terrains (Pilkington and Keating, 2004).

\section{Geophysical data description}

A combined helicopter-borne magnetic, EM, and VLF survey of the Sudbury Structure was acquired in 1987 for Falconbridge Limited (now Xstrata) by Aerodat Limited. The helicopter was nominally flown at $60 \mathrm{~m}$ above the ground towing two geophysical sensors: a four-frequency EM system and a cesium vapor magnetometer sensor, each 30 and $13 \mathrm{~m}$ below the aircraft, respectively. The average nominal flight line spacing was $100 \mathrm{~m}$, and the flight line azimuth was from $150^{\circ}$ to $330^{\circ}$, depending on the prevailing strike direction of the major geologic structures.

Additional aeromagnetic data incorporated in this study include a multisurvey compilation completed by McMaster University for Wallbridge Mining. This compilation included data from more than 31 individual magnetic surveys that covered segments of the footwall area of the North Range and the East Range (H. Ugalde, personal communication, 2011). After individually microleveling each survey, all the data were merged into a single master grid with a spatial resolution (grid cell) of $50 \mathrm{~m}$. To fill in the gaps in between the surveys, and expand the coverage area, the Wanapitei Lake magnetic grid (100-m cell size, L'Heureux et al., 2003), and the

Total Magnetic Intensity Map of the SUDBURY STRUCTURE

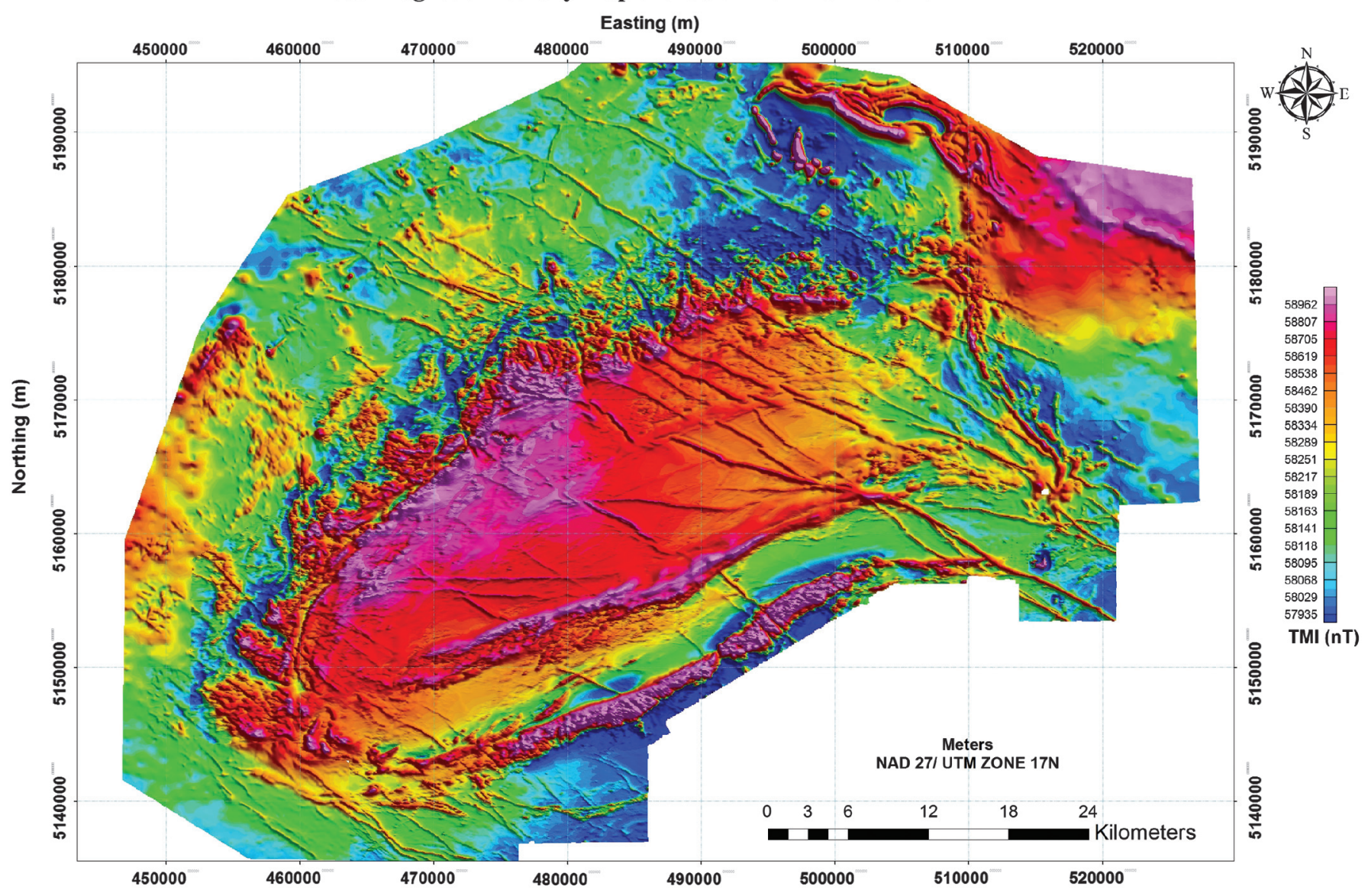

Figure 3. Merged total magnetic intensity field of the Sudbury Structure. The SIC rocks, dense Levack gneisses, and the northwest-trending dykes are characterized by high magnetic intensity, whereas the Huronian supergroup to the south and the Archean rocks in the north exhibit low to moderately high magnetic intensity. 
Geological Survey of Canada (GSC) magnetic data (250 m cell size) were systematically regridded to $50 \mathrm{~m}$, merged, and microleveled with the footwall magnetic data.

For this study, Xstrata's Aerodat, GSC, and the Wallbridge Mining magnetic grids (Table 1) were merged into a single composite grid, and it is this data set that forms the basis of the interpretation presented herein.

\section{Magnetic data processing method}

A simple magnetic processing workflow was developed to prepare the magnetic data set, eliminate nongeologic noise, and merge the data sets obtained from different sources. Grid enhancement and contact mapping techniques were applied afterward, to enhance the shorter wavelength of the magnetic data, which corresponds to near-surface magnetic contacts and lineaments.

The initial gridding of the line data was done to explore the data set, assess the quality, and to have previous knowledge of the data attributes such as flight azimuth and spatial coverage of the data set. The Geosoft Oasis Montaj minimum curvature or random gridding algorithm (RANGRID) was used with a multiple of trial cell sizes of 20,25 , and $30 \mathrm{~m}$. The RANGRID cell size should not be much less than half the nominal data point interval found in the areas of interest (Geosoft technical workshop note). For the Sudbury data set, the 20-m cell size grid had the best resolution and showed the highest continuity of subtle linear structures, so this cell size was selected for further processing. Lots of high-frequency data and nongeologic features were observed in the directional derivatives of the higher derivatives of the gridded magnetic data, especially in the flight line direction (Figure 2a). The flight line artifacts are probably due to the aircraft heading effects or diurnal variations.

A rigorous Minty microleveling technique (Minty, 1991) was performed on the data set to remove the artifacts along the flight lines. This procedure is very labor intensive because of the multiple different flight directions involved. This required that the composite data set be divided into smaller data sets with a single flight line direction, so that each one could be individually microleveled. The Minty microleveling process was implemented in Oasis Montaj using the Butterworth and the directional cosine filters. The Minty method aims to generate an error grid, which consists of long

TMI Vertical Derivatives Map of the SUDBURY STRUCTURE

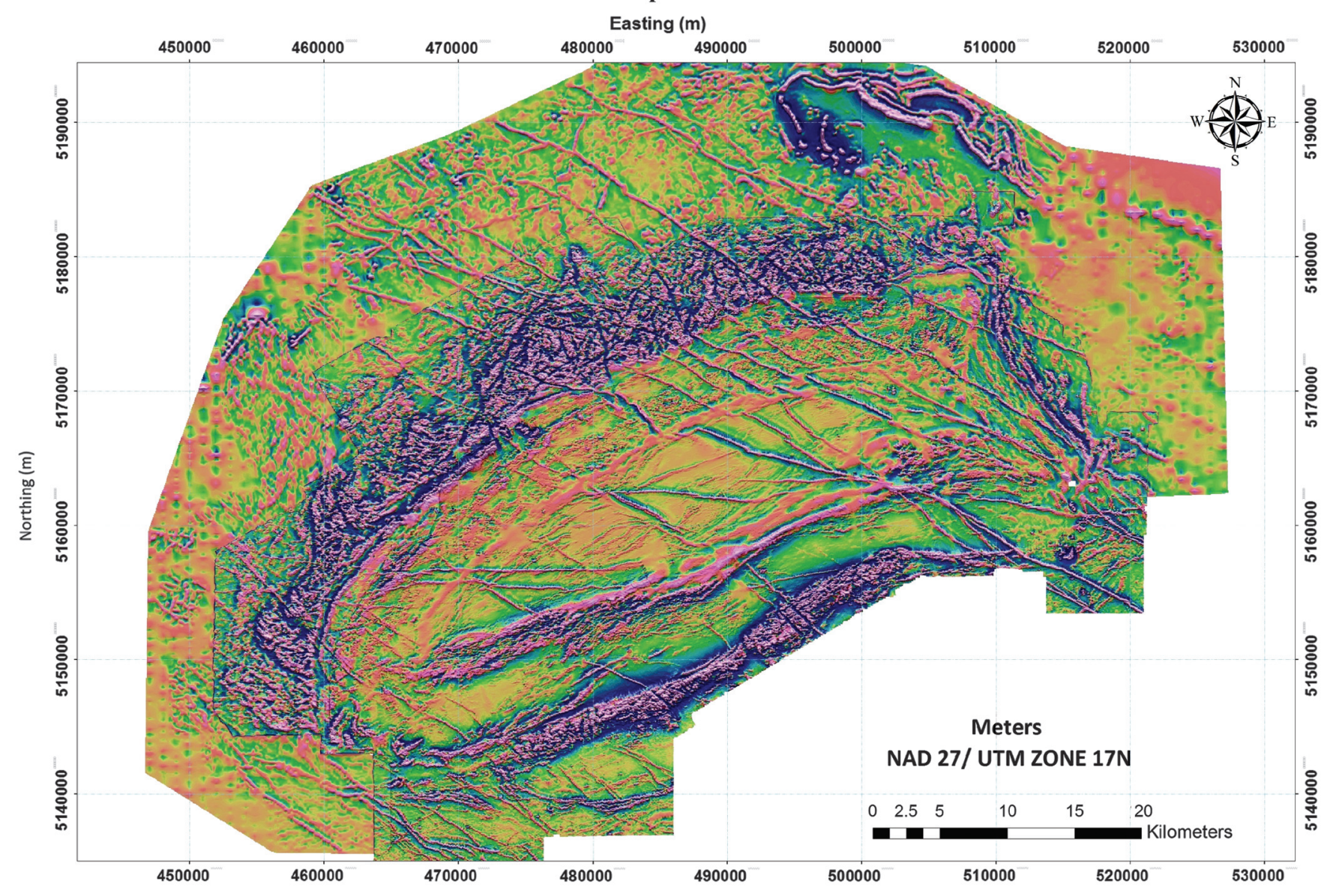

Figure 4. Composite map of transparent colored and grayscale images of the TMI VDRs enhances different magnetic fabrics and lineaments in the magnetic data. 
wavelengths along and short wavelength across the flight lines. For each set of data with the same flight line direction, three filters were applied: (1) a filter with a cut-off wavelength of four times the flight line spacing using a high-pass Butterworth filter of sixth order across the flight lines and (2) with a low-pass directional cosine filter (power of 1.0) along the flight lines. The output of this filter is the residual noise grid. (3) The second low-pass filter was applied iteratively on the residual noise grid, until it was believed that only the nongeologic long-wavelength noises along the flight lines were isolated. The low-passed error grid was then subtracted from the original grid to obtain the microleveled grid. If successfully applied, the first vertical derivative (VDR) of the TMI should contain little evidence of any flight line striping apparent in the raw data (Figure 2b).

The microleveled grids of the magnetic data covering the SIC at 20-m cell size was merged with the lower resolution 50-m cell size data set covering about $10 \mathrm{~km}$ of the footwall rocks from the SIC contact using the Boolean function "OR" in the grid merging module of the Geosoft Oasis Montaj (Figure 3). Although the merged data set has lower resolution outside the SIC contact, some major linear magnetic anomalies were traceable from the higher resolution coverage into the lower resolution part. Figure 3 shows the merged total-magnetic-intensity field of the Sudbury Structure. The elliptical shape of the SIC is well defined by features with high magnetic intensity. In the North Range, norite and gneisses have the highest magnetic intensity especially in the western half of the North Range. Onaping, basal Onaping, and the norite exhibit high magnetic intensity in the South Range. Most dykes have a distinct high magnetic intensity, whereas discontinuities and faults in the North Range have a low magnetic signature. A zone of discontinuity exists at the contact between the North Range and the East Range.

\section{Magnetic data transformation and enhancement}

Total magnetic intensity (TMI) data are a reflection of the spatial distribution of magnetic minerals. Depending on the rock type present, the magnetic signal can be controlled by a small percentage of ferromagnetic minerals such as magnetite and pyrrhotite or a large concentration of more weakly magnetic minerals such as chlorites, amphiboles, and some clays. The magnetic signal does not represent standard geology, which is based on the concentration of silicate minerals. The amplitude and wavelength of the magnetic spectrum are dependent on the vertical separation between the magnetometer and the magnetic source

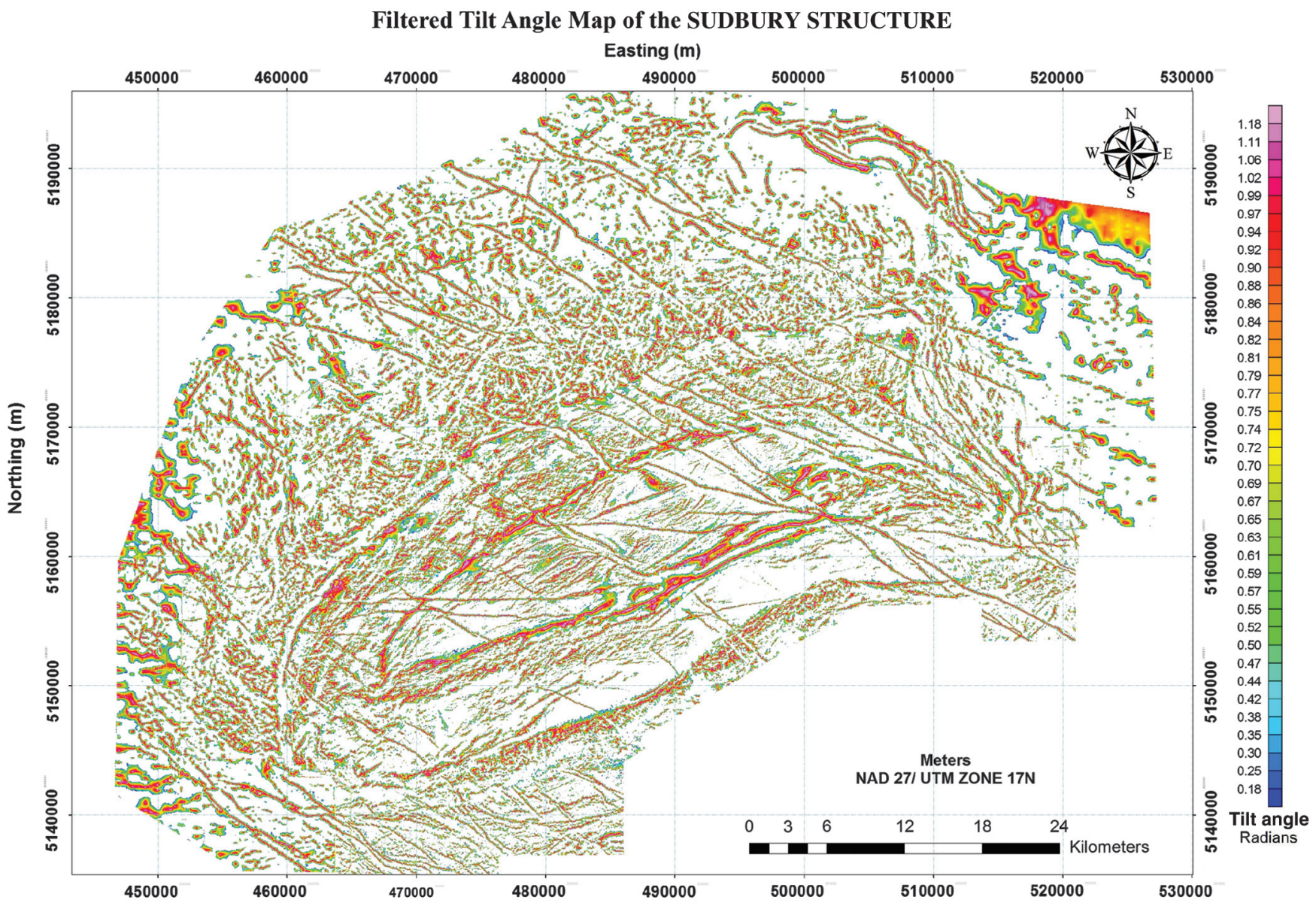

Figure 5. Filtered tilt angle derivative of the TMI further amplifies subtle signals and high magnetic lineaments. 
(Reeves et al., 1997). The magnetic spectrum is made up of a wide range of short- and long-wavelength information, which depicts near and deeper sources (Spector and Grant, 1970). Although shorter wavelengths are not likely to be deep seated, long-wavelength variations can be attributed to deep and shallow sources. Subsurface geologic evidence shows that the SIC rocks that occur on the surface are continuous to more than a 3 -km depth. This configuration makes it difficult to isolate the residual due to near-surface sources from the regional field due to the deeper sources (Hearst and Morris, 2001). The distribution of magnetic minerals within a particular rock unit might not be homogeneous due to alteration and metamorphism (Grant, 1985). A continuous rock unit can exhibit higher or lower magnetic intensity where there are altered or unaltered magnetic minerals. Caution and good knowledge of the geology of the project area are important when processing and interpreting a magnetic data set.

Traditional contact mapping techniques for gridded geophysical data have been developed over the years. Some contact mapping techniques exhibit maxima, whereas others highlight an inflection between positive and negative features over the magnetization contrast (Pilkington and Keating, 2010). Contact mapping and edge enhancement techniques on gridded data are accomplished using a convolution spatial filter or by multiplying the transformed data with the equivalent of the spatial filter in the frequency domain (Milligan and Gunn, 1997). Magnetic sources differ in shape, size, depth, and geometry; therefore, a single enhancement method cannot provide accurate contact or edge information for all magnetic sources (Pilkington and Keating, 2010). Hence, a combination of contact mapping techniques was used to delineate the magnetic contacts and lineaments in the Sudbury Structure. Interpreting more than one magnetic derivative was helpful, because subtle features are more visible in some products than in others.

Some derivatives are in specific directions such as the VDR (Hood, 1965), total field horizontal derivative (THDR) (Grauch et al., 2001), or a combination of these (analytical signal amplitude) (Hsu et al., 1996). Lower or higher order directional derivatives are sometimes normalized to amplify the weak, small amplitudes relative to the stronger, larger amplitude anomalies (Fairhead and Williams, 2006). Normalized derivatives such as the tilt angle (Miller and Singh, 1994), the theta derivative (Wijns et al., 2005), the Horizontal Tilt angle derivative (TDX) (Cooper and Cowan, 2006), and the horizontal derivative of tilt (Verduzco et al., 2004) have

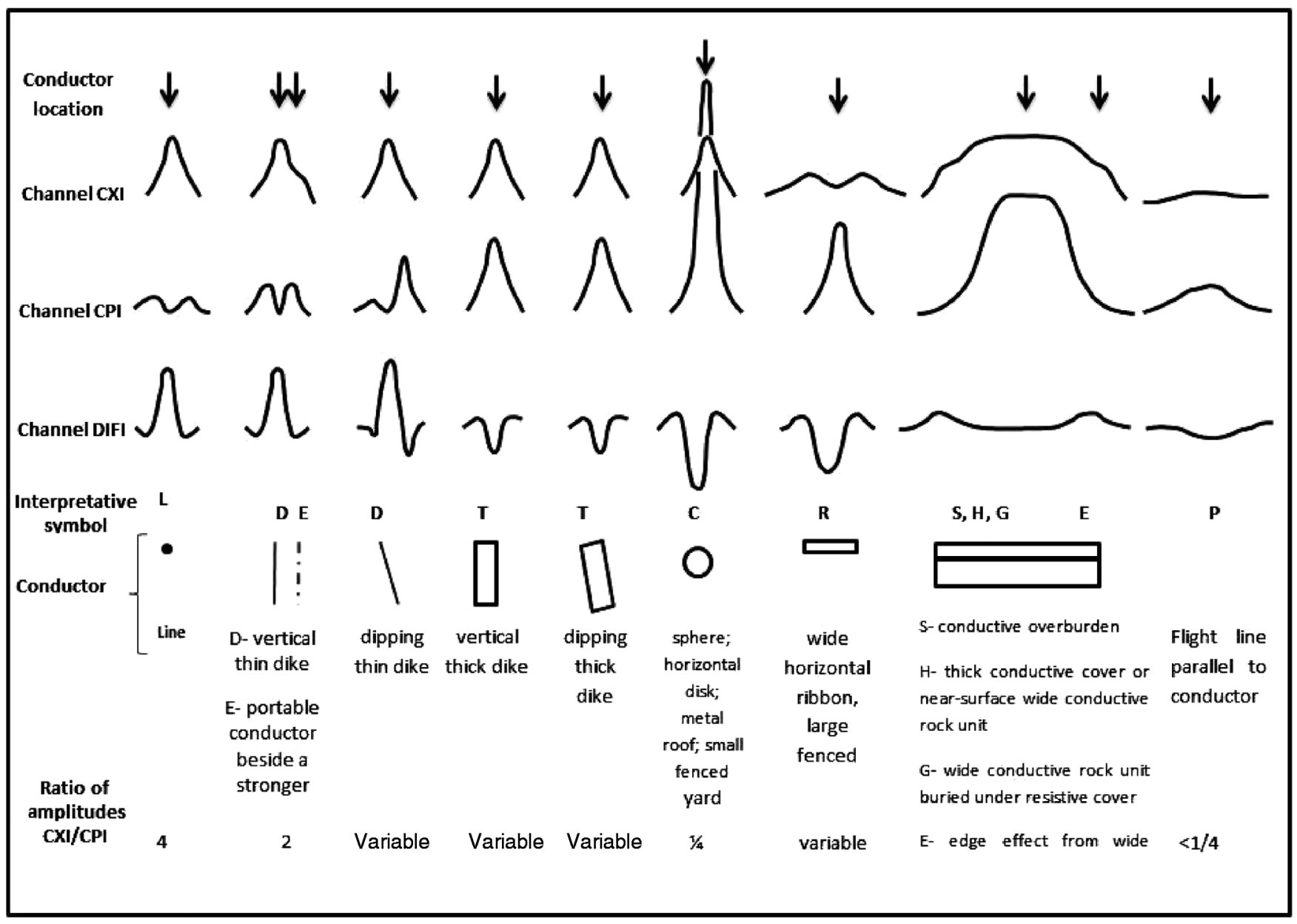

Figure 6. Shapes of theoretical HEM anomalies caused by simple conductors (after Fraser, 1996). 
been implemented to enhance near-surface magnetic contacts and structures. Other higher order functions such as 3D local wavenumber (Smith et al., 1998) are based on second- or third-order derivatives that require very high signal-to-noise ratios.

The accuracy of the directional and normalized contact mappers depends on the data quality as well as the geometry of the body. Edges of dipping contacts might not be accurately enhancedbecause most of the techniques work best at the highest gradient contrast. Some derivatives are excellent in mapping the edges of vertical contacts, whereas others are more suitable for lateral and textural variation. A recent evaluation of some contact enhancement techniques showed that most of the recently introduced enhancements using higher derivatives are strongly related to the older enhancements, and they are therefore redundant for contact mapping (Pilkington and Keating, 2010). This current work does not intend to reevaluate the different techniques; for further reading, see Fairhead and Williams (2006), Pilkington and Keating (2004, 2010), and references therein.

Our approach was to map contacts and lineament using directional and normalized derivatives such as the
VDR (Hood, 1965), the THDR (Grauch et al., 2001), the tilt derivative (Miller and Singh, 1994), the TDX (Cooper and Cowan, 2006), and the analytical signal amplitude (Hsu et al., 1996). Directional derivatives, vertical (VDR, Figure 4) and horizontal (THDR) were calculated to accentuate the shorter wavelength portion of the magnetic spectrum, which corresponds to the near-surface geologic structure. The tilt derivative (Figure 5) and TDX of the TMI were calculated from the directional derivatives. Tilt angle values are restricted to lie between $-\pi / 2$ and $+\pi / 2$, regardless of the amplitude of the VDR or THDR (Miller and Singh, 1994). The tilt and TDX derivatives enhance subtle anomalies and form amplitude peaks over magnetic sources.

A combination of the red-green-blue and grayscale of the VDR image (Figure 4) enhances the magnetic fabrics of the different rock units, linear discontinuities, and structural patterns within the highly heterogeneous Levack gneiss complex underlying the North Range and the East Range of the SIC. The filtered tilt derivative grid of values greater than 0 isolates peaks of highly magnetic lineaments, which are mostly northwest-trending dykes and contacts (Figure 5). Subtle southwest-trending features displaced by the

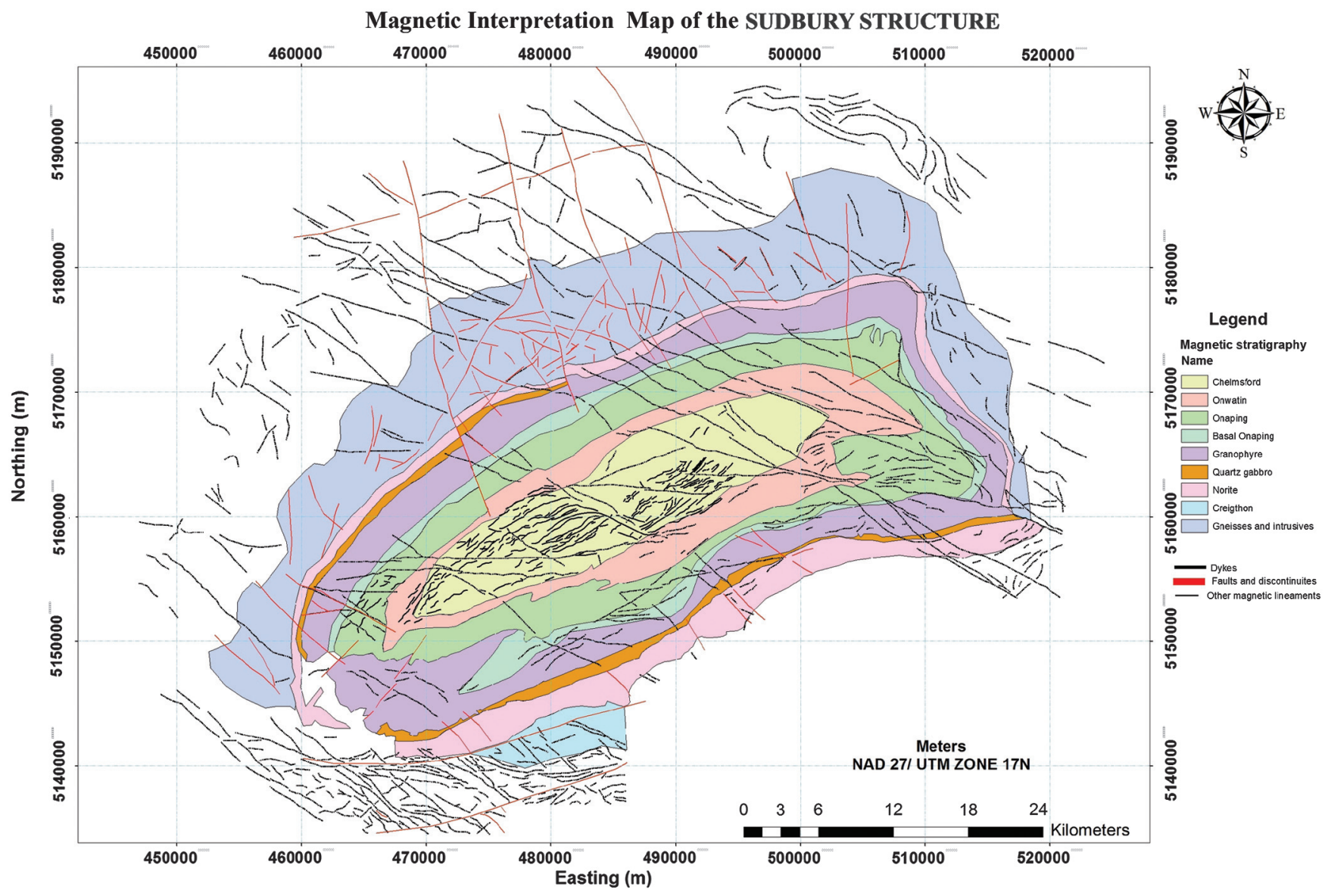

Figure 7. Geophysical interpretation map of the Sudbury Structure. Magnetic stratigraphy is determined based on qualitative classification of magnetic fabrics representing different rock units. Magnetic discontinuities were mapped as faults, dykes, and other magnetic lineaments. 
northwest-trending dykes within the Chelmsford are also further enhanced in the tilt derivative.

\section{On-screen contact and lineament mapping}

Information extraction was done in a GIS using the ESRI ArcMap. All features on a map are represented in a GIS as points, lines, and polygons. Points are discrete features with just $X Y$, e.g., peak of EM anomaly, borehole location; lines are a series of discrete points $X_{1} Y_{1} X_{2} Y_{2} X_{3} Y_{3} \ldots X_{i} Y_{i}$, e.g., lineaments, roads; and polygons are a series of discrete points that begin and end at the same point $X_{1} Y_{1} X_{2} Y_{2} X_{3} Y_{3} \ldots X_{1} Y_{1}$, e.g., lithological units, lakes, etc. The scale of the map will influence which GIS object would be used to present a feature. A lithological unit or dike represented by a polygon at a large scale (1:2000) will become a point or line, respectively, at a smaller scale (1:100,000).

Part of the objective of this study was to compare the lineaments extracted from magnetic data with the published bedrock geologic map (Ames et al., 2005). This was produced and published at 1:50,000 using the Universal Transverse Mercator North American Datum (NAD) 1927 coordinate system, so all the geophysical data sets were reprojected to NAD 27 and information extraction was concentrated on more regional features at a scale of 1:75,000. Magnetic contacts and lineaments were first mapped as lines based on magnetic fabrics, magnetic peaks, contrasts, and discontinuities.

\section{Qualitative EM mapping}

EM surveys respond to conductivity variations in the subsurface. Using EM data for mapping entails identification of anomalous conductive zones or discrete locations along the traverse. The anomaly pattern varies and depends on the configuration of the transmitterreceiver (coaxial or coplanar) as well as the conductivity and geometry of the body. Frequency-domain EM data available for this project were helicopter EM (HEM) data acquired with the Aerodat system using coplanar (32,000 and $4175 \mathrm{~Hz})$ and coaxial (4600 and $935 \mathrm{~Hz}$ ) coil pairs. Figure 6 shows the theoretical HEM anomalies caused by simple conductors (Fraser, 1996).

Components of the secondary field at varying frequencies in the coplanar and coaxial modes were interpreted. The primary field of the coaxial transmitter is horizontal directly beneath the system; hence, its couples well with steeply dipping bodies perpendicular to the flight line (Fraser, 1996). In coaxial mode, the EM

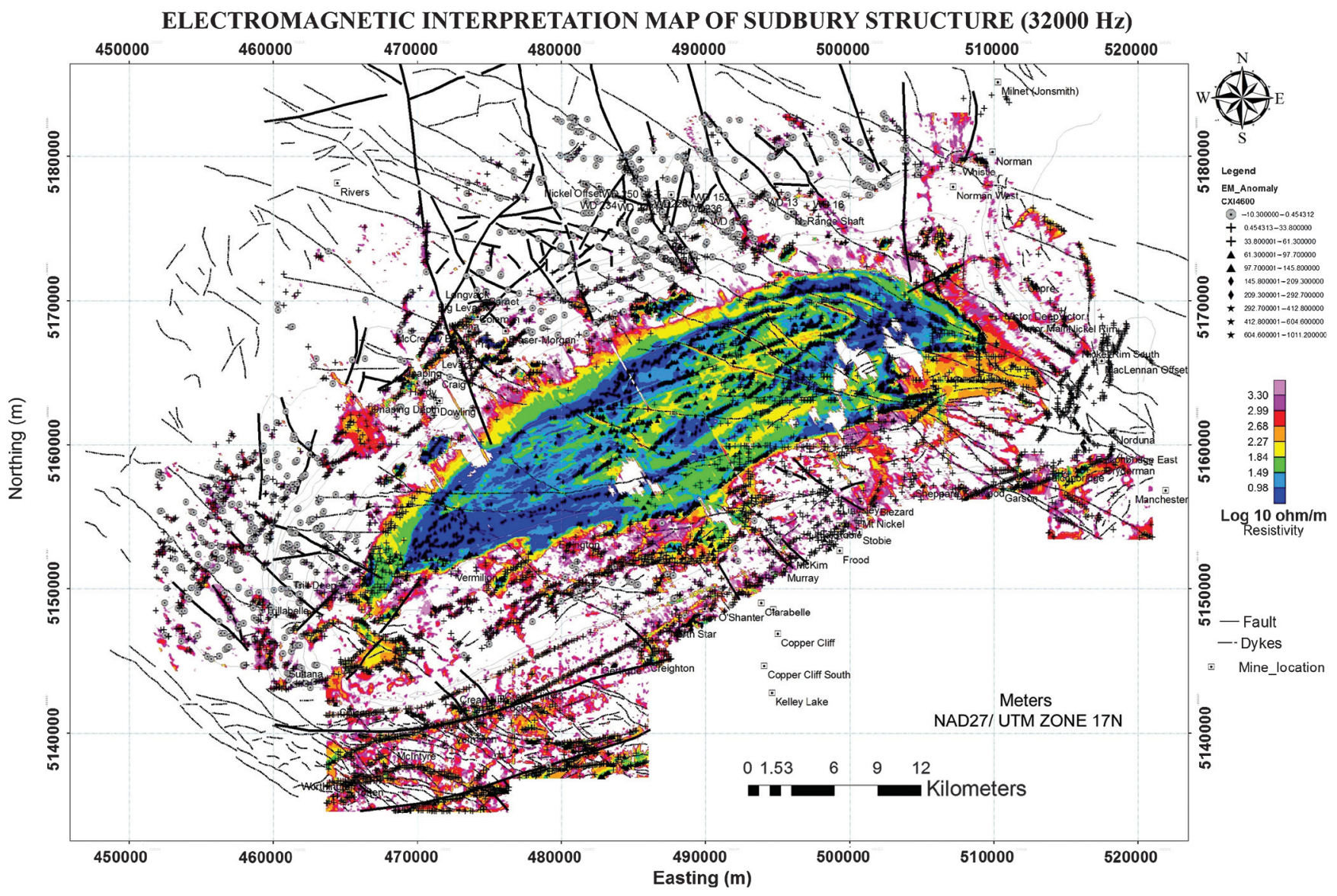

Figure 8. EM anomaly map of the Sudbury Structure with a filtered resistivity grid as the colored background. The Fecunis area is the black rectangular box that is enlarged and further discussed below. Blue indicates very low resistivity, orange and yellow are moderately low resistivity, and pink and red are low resistivity. 
responses mostly peak over the conductive bodies shown in Figure 6; the exception is an extensive horizontal sheet with sharp edges. The coplanar response is more diagnostic of the geometry of this horizontal conductor (Fraser, 1996). The aim of the project was to interpret conductive structures, specifically faults or shear zones; therefore, the EM response in the coaxial mode at frequencies of 4600 and $935 \mathrm{~Hz}$ were interpreted. The apparent resistivity grid at $32,000 \mathrm{~Hz}$ was also computed from the leveled in-phase and quadrature components of the coplanar mode.

Quantitative interpretation of the conductive features was done interactively in geophysical software by displaying each of the EM profile data and manually selecting anomaly peaks. This process is very subjective because it depends largely on the range between the highest and lowest amplitude values along each profile. A relatively small EM anomaly peak on a profile might disappear on the next profile if it is superimposed on a broad large amplitude anomaly.

\section{Results \\ Magnetic interpretation map of the Sudbury Structure}

In addition to the different magnetic mineral content of rocks within the Sudbury Structure, there are also different magnetic fabrics evident. This could be related to the grain shapes and preferred crystallographic orientation of the ferromagnetic and paramagnetic minerals in the rock units (Hrouda, 1982), or it could be a reflection of the structural deformation, diagenesis, or the manner in which the rocks were deposited (e.g., turbidites). Magnetic stratigraphy contacts were solely differentiated based on qualitative classification of the magnetic fabrics. The differing magnetic textures were qualitatively classified, and the point at which the magnetic fabrics changes to another is judged to be the contact of the two magnetic units. These contacts were digitized and polygonized to generate a magnetic stratigraphy map of the Sudbury Structure.

The extracted linear information was thereafter classified either as a lithological contact, a fault, a dike, or some other lineament. When there was a close association or spatial relationship with a known feature on the published geologic map, that information was used in the classification. Major faults generally occur as discontinuities within the rocks and exhibit a very low magnetic signature. This low magnetic signature exhibited by faults could be due to (1) infilling of the fault zone with nonmagnetic materials, (2) oxidation of the magnetite at the fault plane due to exposure, and (3) juxtaposition of displaced rocks against nonmagnetic

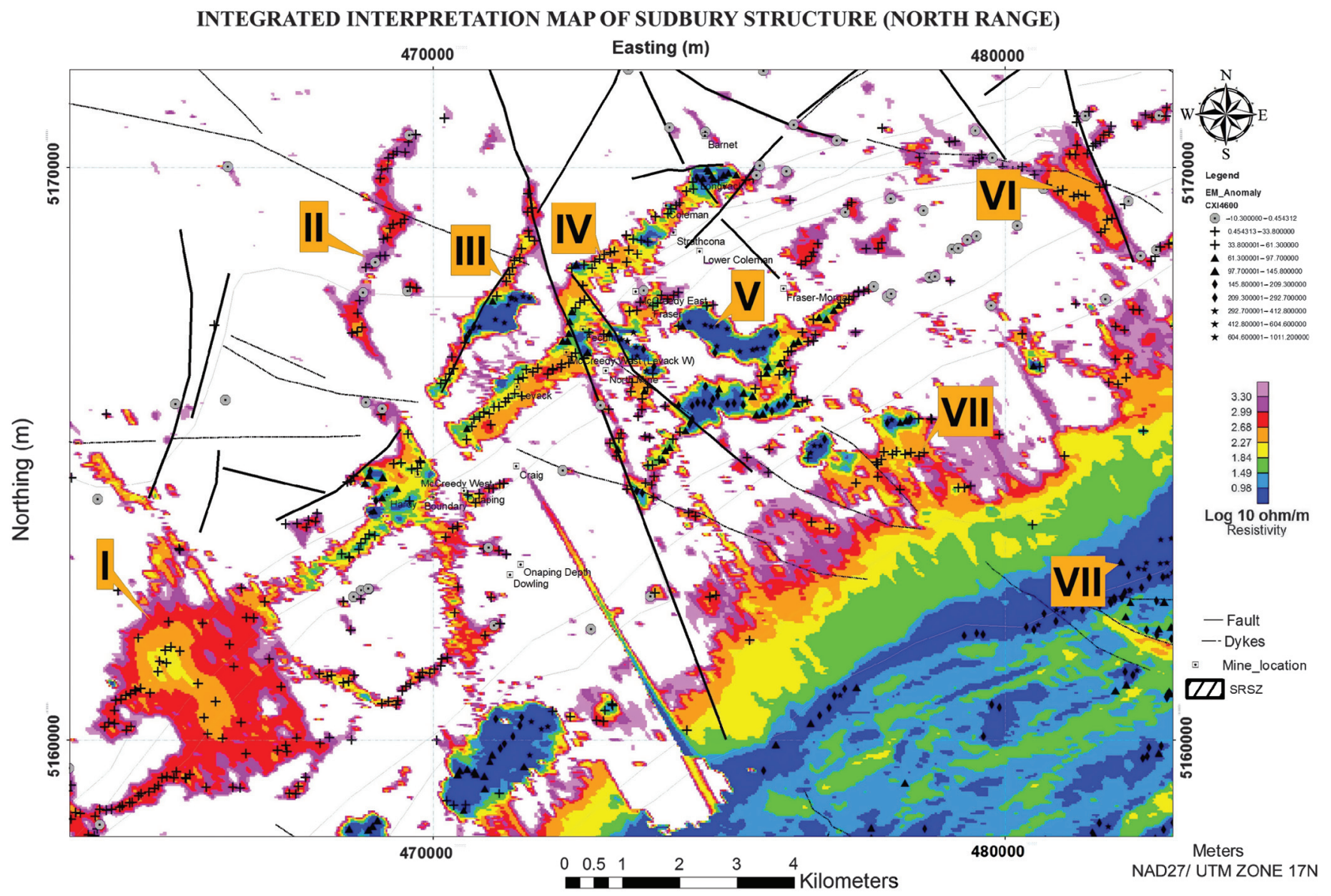

Figure 9. EM anomaly map of the Fecunis area (North Range). Features I-VIII in the North Range are some of the EM anomalies discussed in the text. 
rocks. Mafic dykes, which dominate the Sudbury Structure, are rich in magnetic minerals (magnetite, pyrrhotite), and the dykes therefore exhibit a very high magnetic signature relative to their host rocks. Most of the dykes occupying fault zones, e.g., olivine diabase dykes, display relatively low magnetic signature in the Sudbury region, particularly where they crosscut a more magnetic rock such as the SIC in the North Range. Integration of the magnetic stratigraphic map and lineaments generated a magnetic interpretation map of Sudbury Structure, which is entirely based on the distribution of the magnetic minerals in the rocks and structures (Figure 7).

\section{EM map of the Sudbury Structure}

In the interpretation of the EM data, $7940 \mathrm{EM}$ anomaly peaks were selected from the 1881 profile lines using the patterns in Figure 6. The peak locations were plotted as points and symbolized based on the conductivity; however, the large number of anomalies and the fact that the symbols are very small on images suitable for presentation in a scientific paper means that we have also included the gridded apparent resistivity derived from the $32,000 \mathrm{~Hz}$ data (Figure 8). In the resistivity image, the gneissic and granitic rocks in the Superior
Province, the Huronian sedimentary rocks, and some human settlements (Chelmsford, Val Caron, and Hammer) exhibit very high resistivity (greater than $1000 \mathrm{ohm}-\mathrm{m})$. To isolate relatively low resistivity zones and provide better visualization, the highly resistive zones (greater than $1000 \mathrm{ohm}-\mathrm{m}$ ) in the gridded apparent resistivity were not displayed.

There is a wealth of information in Figure 8 about the spatial distribution of conductive features related to metallic ore bodies, lithological contacts, faults, shear zone, as well as man-made features such as power lines, buildings, and railways. Because it is difficult to see this information at the scale presented, we make use of enlargements; for example, the Fecunis area shown as a black rectangular box is enlarged in Figure 9 .

In the main mass, sublayer, and footwall rocks, numerous conductive zones, linear and polygon shaped, are observed. The EM interpretation map shows that (1) most of the known geologic linear features Fecunis, Creighton, Murray faults, and mineralized offset dykes - the Foy and Worthington offsets, are associated with linear and moderately high conductive anomalies, whereas the very highly conductive zones are more closely related to features associated with Whitewater group rocks and (2) some of the nonlinear

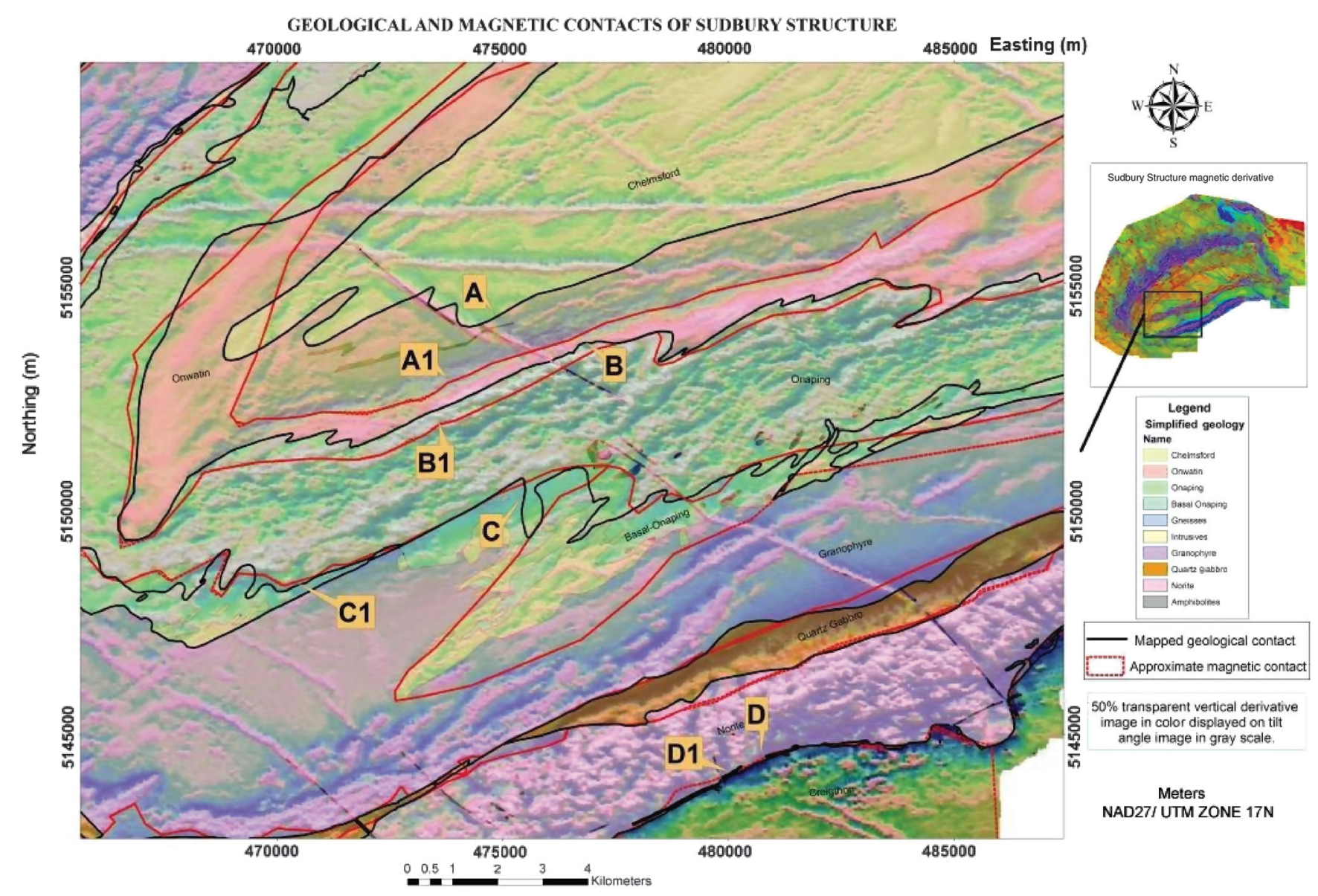

Figure 10. Comparison of the magnetic (yellow) and geologic (red) contacts in the published map of the Sudbury Structure displayed on VDR in grayscale. 
and irregular-shaped low-resistivity anomalies are due to water bodies (Windy, Nelson, Whitewater, and Fairbank lakes), probably due to presence of organic-rich clay or silty materials at the bottoms of the lakes or perhaps to ore bodies under the lakes - e.g., Joe Lake (Watts, 1997).

The very low resistivity exhibited by most parts of the Whitewater Group sedimentary rocks clearly differentiates them from the surrounding SIC rocks, allowing the contact between the Whitewater and the SIC to be qualitatively mapped. High conductivity zones within the sedimentary sequence appear to be due to (1) the presence of carbon in the Dowling and Sandcherry members of the Onaping Formation, (2) the sulfide-rich carbonate of the Vermilion Formation (containing $\mathrm{Pb}$, $\mathrm{Zn}, \mathrm{Cu}, \mathrm{Au}$, and $\mathrm{Ag}$ ), and (3) the pyritic and carbonaceous laminated mudstone of the Onwatin Formation. Carbon in Onwatin has been reportedly metamorphosed into anthraxolite veins (95\% carbon, Burrows and Rickaby, 1930). This could be responsible for some of the linear conductive features observable within the Whitewater Group (Figures 8 and 9).

Several moderately conductive anomalies dominate the boundary between the Southrange Onaping and the
Granophyre. This northeast-trending zone has been reversely sheared (Shanks and Schwerdtner, 1991) and hosts sheared metallic ore type deposits within the Sudbury Structure. Conductive anomalies within this South-Range shear zone may be due to these ore bodies, e.g., at Falconbridge and Garson mines. Lake-bottom sediments - Whitewater, Whitson, and Gorgon lakes within the zone - also exhibit high conductivities.

Figure 9 shows the EM anomaly, gridded resistivity data, magnetic lineament, as well as locations of known deposits and mines. As well, several specific features have been labeled: I, Conductive Windy Lake anomaly; II, faulted conductive feature along Onaping River; III, very conductive anomaly due to structurally controlled Pine Lake; and IV, a linear moderately conductive body in the norite, contact Sublayer, and Footwall breccia area. Some mines and known discoveries are associated with this feature. The linear anomaly is closely related to the access road to the mines: $\mathrm{V}$, very conductive polygonal anomalies due to West Morgan, Morgan, and Moose Lakes. These could be due to mine tailing waste or lake-bottom sediments: VI, very conductive and magnetic feature related to Sandcherry fault; VII, moderately high conductivity in the Onwatin Formation due

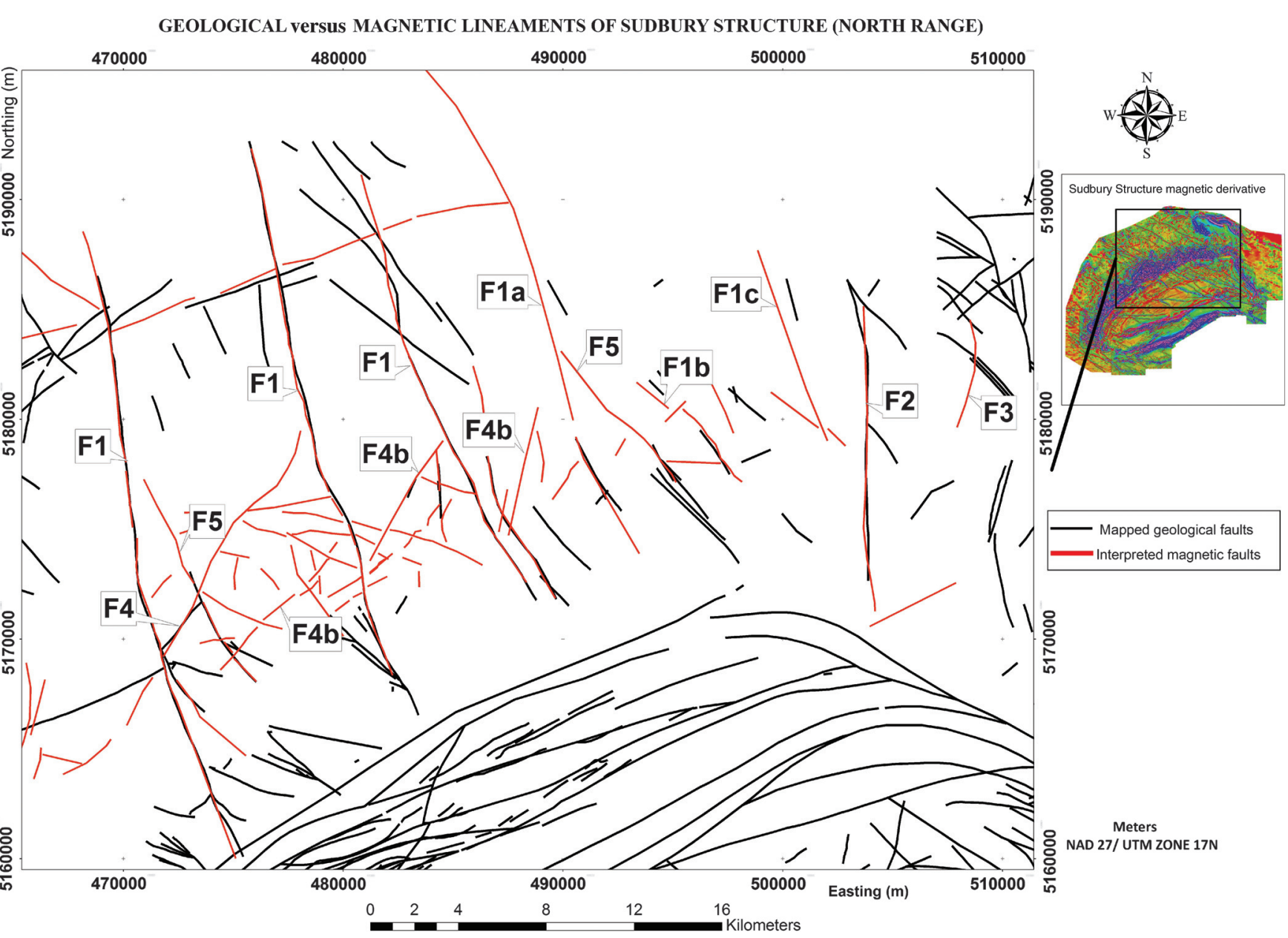

Figure 11. Map of the geologic and magnetic fault sets in the North Range of SIC and footwall rocks. The black lines are the established faults, and the red lines represent the magnetic lineaments from derivatives. 
the presence of carbon, $\mathrm{Zn}-\mathrm{Cu}-\mathrm{Pb}$ mineralizations, and pyrite nodules; and VIII, conductive Onaping Formation due to the presence of carbon in the Sandcherry and Dowling members.

\section{Bedrock geology map versus geophysical interpretation map}

Comparison of the published bedrock map and the magnetic interpretation was done by overlaying the established geologic boundaries and structure on the interpreted magnetic contacts and lineaments. This was done to access the quality of the geophysical interpretation work done and identify the value added by the magnetic interpretation.

\section{Geologic contact versus magnetic contact}

The delineated magnetic contacts are mostly oriented in the same direction as the defined lithological boundaries in the bedrock map, but they are offset from the geologic boundary at some places (Figure 10). These offsets could be related to the different degrees of alteration and destruction of magnetic minerals in the rocks at contacts, or perhaps there were problems in the geologists identifying and mapping the contacts due to inaccessibility issues, e.g., swamps, lakes, etc., leading to extrapolations or interpolations on the geologic map. Also, alteration of magnetic minerals may not change at geologic contacts or may be hard to identify in the field and hence the map. The black lines represent the geologic contacts defined by field mapping, and the red lines represent locations where magnetic fabrics change to another depicting a change in the rock unit: Chelmsford-Onwatin contact (geologic $=\mathrm{A}$, magnetic $=\mathrm{A} 1)$, Onwatin-Onaping contact $($ geologic $=\mathrm{B}$, magnetic $=\mathrm{B} 1$ ), Onaping-Granophyre (geologic $=\mathrm{C}$, magnetic $=\mathrm{C} 1$ ).

The spatial resolution of the airborne data imposed a limit on the level of accuracy of the positions that can be ascertained from the image. Magnetic zones with dimensions below or close to the grid cell sizes $(20 \times 20 \mathrm{~m}$ within the SIC and $50 \times 50 \mathrm{~m}$ in the footwall rock) are difficult to identify and approximate on the map. The first VDR of the magnetics, shown in grayscale as the background to Figure 10, highlights the

GEOLOGICAL versUS MAGNETIC LINEAMENTS OF SUDBURY STRUCTURE

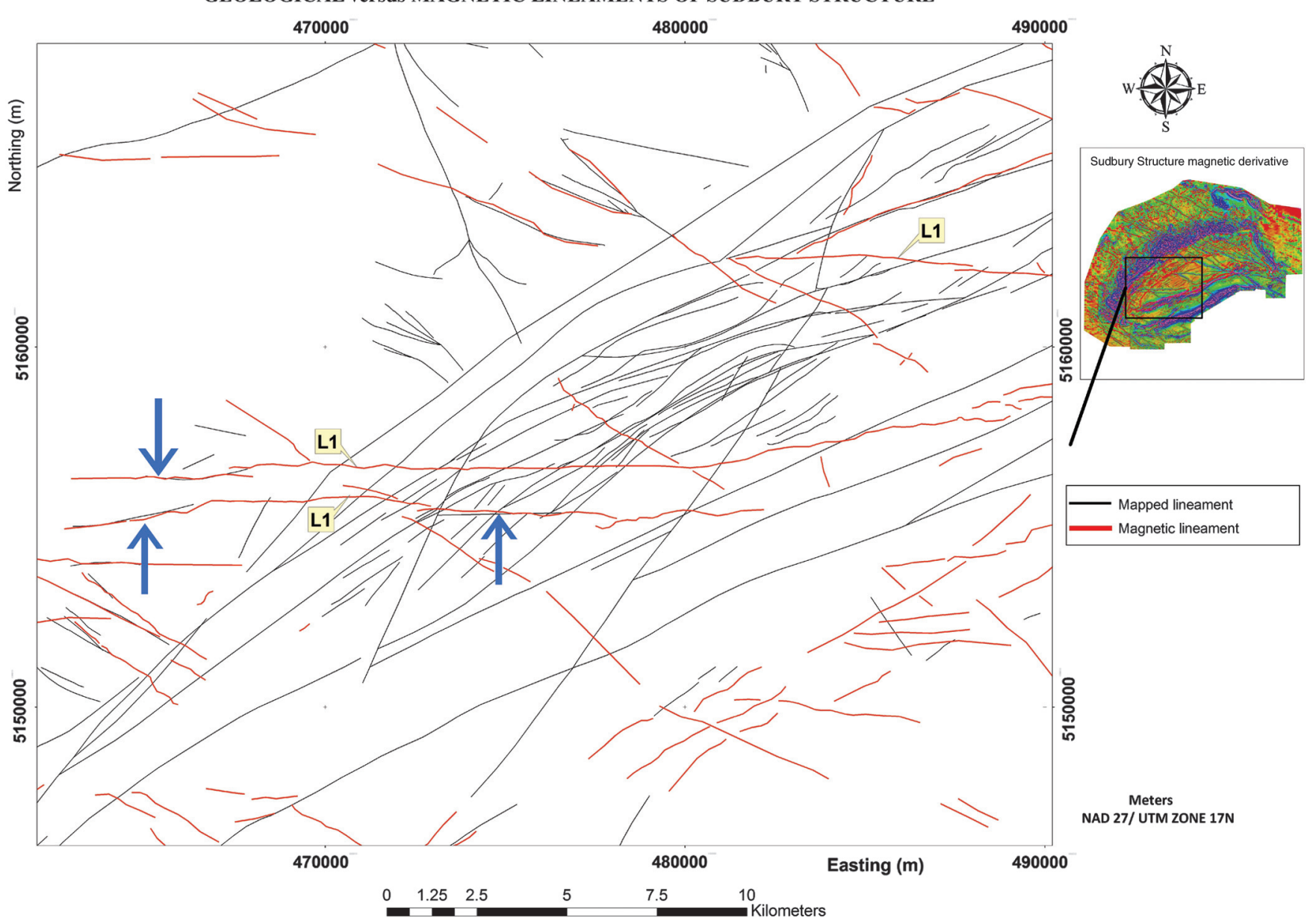

Figure 12. Map of the geologic and magnetic fault sets in the western part of the SIC area. Three parallel east-west lineaments, possibly dykes, have been labeled L1. Where these have been more extensively mapped on the geophysics, they are marked with blue arrows. 
different magnetic fabrics of different rocks of the Whitewater group and the SIC: Chelmsford (dark and moderately coarse), Onwatin (very bright and smooth), Onaping (bright and very coarse), and Granophyre (relatively darker and less coarse than Onaping).

\section{Sudbury Structure geologic and magnetic lineaments}

Mapped geologic structures such as the north-south Fecunis Lake and Sandcherry faults (that displaced the rocks of the Sudbury Structure in the North Range) and the Murray and Creighton faults all coincide with the magnetic discontinuities in the VDR, whereas some northeast olivine diabase and offset dykes - Foy and Hess - are delineated by magnetic peaks in the tilt derivative. Figure 11 shows the geologic and magnetic fault sets in the North Range of the SIC and footwall rocks. The black lines are fault sets that have been established geologically, and the red lines represent the magnetic lineaments from derivatives. Although the location of the magnetic feature deviates from the geologic lineaments at some points along the drawn line, their overall location and orientation imply that the geophysical feature is due to the geologic structure. Similarly, some interpreted lineaments are further extensions of known geologic structures, whereas others are newly identified lineaments. Some known geologic structures that were partially mapped in the bedrock map due to lack of exposures are more continuous in the magnetic derivative maps.

Figure 12 shows four parallel east-west lineaments (L1). The blue arrows indicate locations where they have been previously mapped in the field. The L1 features extend from the western part of the North Range into the South Range where they have been highly deformed and displaced. Some of the Sudbury swarm dykes were only partly mapped, whereas some have not previously been mapped (Figure 13). These northwest-trending dykes are only partly mapped on the geologic map, but a greater extent is evident on the geophysical interpretation (red lines). Also, the displacement patterns of the Sudbury swarm dykes are evident from the geophysics. Table 2 gives further details of the comparison of the geologic and

GEOLOGICAL versUS MAGNETIC LINEAMENTS OF SUDBURY STRUCTURE (DYKES)

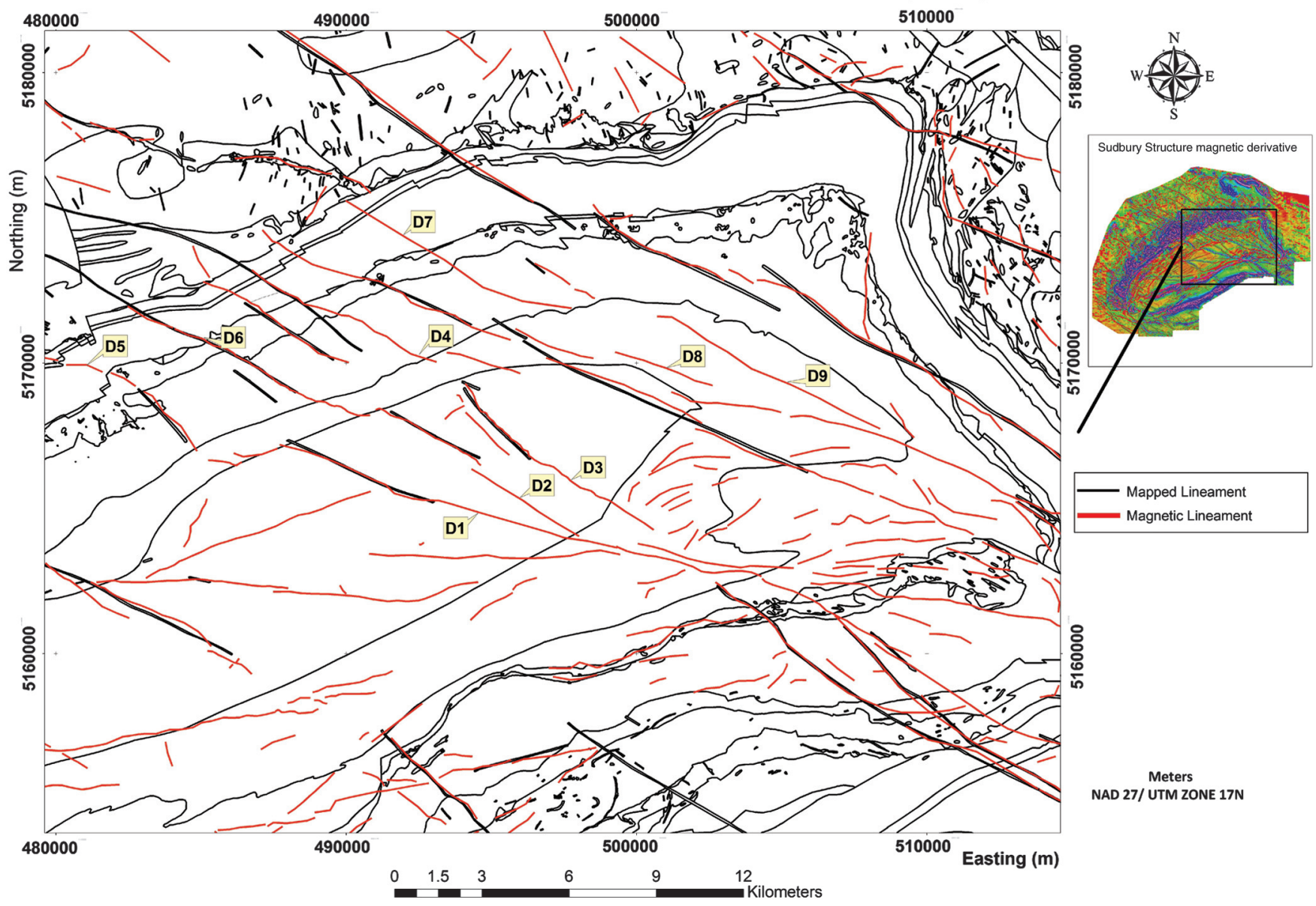

Figure 13. Map of the geologic and magnetic fault sets in the northeast part of the SIC. Partly mapped northwest dykes are shown in black, and the red lines show the full extent and the displacement patterns of the Sudbury swarm dykes. 
F1 Fecunis fault set - Three northwest-striking lineaments, extends 20-30 km from the SIC contact into the north range.

F1a Fecunis fault set? Northwest-striking lineament, extends about $25 \mathrm{~km}$ from the SIC contact into the North Range footwall rocks.

Fecunis fault set? Northwest-striking lineament, extends about $6 \mathrm{~km}$ from the SIC contact into the North Range footwall rocks.

F1c Fecunis fault set? Northwest-striking lineaments, extends $9.3 \mathrm{~km}$ from the SIC contact into the North Range footwall rocks.

F2 Almost north-south-striking lineament, extends $13 \mathrm{~km}$ from the SIC near the contact of the North Range and the East Range.

F3 Northaest-striking lineament, extends $5.1 \mathrm{~km}$ into the footwall rock at the contact of the North Range and the East Range.

F4 Northeast-striking lineament, extends $19 \mathrm{~km}$ through Fecunis to Sandcherry fault.

F4b Two northeast-striking lineaments extends $6 \mathrm{~km}$ from Sandcherry fault to the third northwest fault and another one from the F1 fault to the F1a fault. They displace the Foy offset dykes.

F5 Two northeast-trending lineament at an angle a little less than the Fecunis fault set.

L1 Three east-west-trending dykes, stretching from the western part of the North Range into the South Range and furthermore.

D1-D9 Nine northwest dykes of varying length cutting across most rock of the Sudbury Structure and have been faulted at some points.
Fully mapped; magnetics and geologic interpretation correspond. Very small offsets from the geologic and magnetic interpretations where they have both been mapped.

Lower part close to the SIC was partially mapped out by field mapping. The part of fault in the footwall rocks was interpreted from the magnetic derivative.

Partially mapped with little offset. The magnetic lineament is more extensive and displaced by a northeast fault.

Not mapped before; new magnetic interpretation.

Partially mapped geologically in parts. The lineament continuity is interpreted from the magnetic derivatives.

Not mapped before; new magnetic interpretation.

Partially mapped. Lineament is more extensive in the magnetic derivative.

Not mapped before; new magnetic interpretation.

Partially mapped on the bedrock map.

Mapped in parts within the Chelmsford Formation. New four east-west magnetic dykes parallel to each other were interpreted from the magnetic derivatives.

All partially mapped. The magnetic derivatives showed that they continue from the South Range, through the Whitewater group sediments into the

North Range and footwall rocks. Northeast-trending faults have displaced some of the dykes. magnetic fault, dike, and other lineaments seen in Figures $11-13$.

\section{Conclusion}

Directional and normalized derivatives of the TMI enhanced the mapping of the near-surface contacts and lineaments. The geophysical information interpreted shows that some lineaments were omitted from the geologic map, whereas most are more extensive than previously indicated. The magnetic stratigraphy contacts defined based on qualitative classification of the magnetic texture showed that magnetic contacts do not always correspond to geologic boundaries in the existing map. In some locales, this difference translates into significantly different thickness estimates for some rock units. This discrepancy might warrant more detailed geologic mapping and studies of the rocks to better understand the geologic explanation for the differences between the published geologic map and the geophysical interpretation.

Conductive locations identified from the EM profiles are probably due to responses from lake sediments, conductive ore bodies, faults, dykes, lithological contacts, and geologic noise. The Onwatin Formation is composed of conductive carbonaceous mudstones, and this has been mapped successfully with the EM data. Further investigations are required before drawing any definite conclusions about the low-resistivity zones associated with known host rocks within Sudbury structures such as the contact Sublayer, offset dykes, Sudbury and footwall breccia, and the South Range shear zone. The locations of faults and shears identified in the EM can be used to justify faults and other structures that are required in the inversion modeling we intend to undertake. The dykes identified from the magnetic data must also be incorporated in the magnetic modeling. In some cases, these dykes appear to offset the stratigraphy, so they should also be interpreted as faults.

\section{Acknowledgments}

Thanks go to NSERC, Vale, Xstrata Nickel, KGHM International, Wallbridge Mining, and CEMI for providing data and financial support. Thanks also go to Darrel Long for his technical input and $\mathrm{H}$. Ugalde for compiling the Wallbridge Mining, GSC, and Wanapitei magnetic data set of the North Range footwall used in this study. 


\section{References}

Ames, D. E., A. Davidson, J. L. Buckle, and K. D. Card, 2005, Geology, Sudbury bedrock compilation, Ontario: Geological Survey of Canada, Open file 4570, Scale 1:50,000.

Ames, D. E., D. H. Watkinson, and R. R. Parrish, 1998, Dating of a regional hydrothermal system induced by the 1850 Ma Sudbury impact event: Geology, 26, 55-100, doi: $\quad 10.1130 / 0091-7613(1998) 026<0447$ :DOARHS $>2.3$ .CO;2.

Bailey, J., B. Lafrance, A. M. McDonald, J. S. Fedorowich, S. Kamo, and D. A. Archibald, 2004, Mazatzal-Labradorianage $(1.7 \mathrm{e} 1.6 \mathrm{Ga})$ ductile deformation of the South Range Sudbury impact structure at the Thayer Lindsley mine, Ontario: Canadian Journal of Earth Sciences, 41, 1491-1505, doi: 10.1139/e04-098.

Bell, R., 1891, On the Sudbury Mining District: Geological Survey of Canada, Annual Report, 5F-95F.

Buchan, K. L., J. K. Mortensen, and K. D. Card, 1993, Northeast-trending Early Proterozoic dykes of southern Superior Province: Multiple episodes of emplacement recognized from integrated paleomagnetism and U-Pb geochronology: Canadian Journal of Earth Sciences, 30, 1286-1296, doi: 10.1139/e93-110.

Burrows, A. G., and H. C. Rickaby, 1930, Sudbury Basin area: 38th annual report of the Ontario Department of Mines.

Card, K. D., 1978, Metamorphism of the middle Precambrian (Aphebian) rocks of the eastern Southern Province, in J. A. Fraser, and W. W. Heywood, eds., Metamorphism in the Canadian Shield: Geological Survey of Canada, 269-282.

Cochrane, L. B., 1991, Analysis of the structural and tectonic environment associated with rock mass failures in the mines of the Sudbury District: Unpublished Ph.D. thesis, Queens University.

Collins, W. H., 1937, Life history of the Sudbury nickel irruptive (4): Mineralisation: Transactions of the Royal Society of Canada, 31, 15-43.

Cooper, G. R. J., and D. R. Cowan, 2006, Enhancing potential field data using filters based on the local phase: Computers \& Geosciences, 32, 1585-1591, doi: 10 $.1016 /$ j.cageo.2006.02.016.

Corfu, F., and A. Andrews, 1986, A U-Pb age for mineralized Nipissing Diabase Gowganda, Ontario: Canadian Journal of Earth Sciences, 23, 107-109, doi: 10.1139/e86-011.

Deutsch, A., R. A. F. Grieve, M. Avermann, L. Bischoff, B. Brockmeyer, D. Buhl, R. Lakoomy, R. Muller-Mohr, M. Ostermann, and D. Stoffer, 1995, The Sudbury Structure (Ontario, Canada): A tectonically multi ring impact basin: Geologische Rundschau, 84, 697-709, doi: 10 $.1007 / \mathrm{s} 005310050034$.

Dietz, R. S., 1964, Sudbury Structure as an astrobleme: Journal of Geology, 72, 412-434, doi: 10.1086/626999.

Dressler, B. O., 1984, General geology of the Sudbury area, in E. G. Pye, A. J. Naldrett, and P. E. Giblin, eds., The geology and ore deposits of the Sudbury Structure: Ontario Geological Survey, 1, 57-82.

Dressler, B. O., V. K. Gupta, and T. L. Muir, 1991, The Sudbury Structure, in P. Thurston, R. Sutcliffe, and G. Stott, eds., Geology of Ontario: Ontario Geological Survey, 4, 593-625.

Fahrig, W. F., and T. D. West, 1986, Diabase dike swarms of the Canadian Shield: Geological Survey of Canada, Map 1627, Scale 1: 4,873,900.

Fairhead, J. D., and S. E. Williams, 2006, Evaluating normalized magnetic derivatives for structural mapping: 76th Annual International Meeting, SEG, Expanded Abstracts, 845-849.

Fraser, D. C., 1996, Geological application of airborne electromagnetics methods: Dighem frequency domain course note.

French, B. M., 1972, Shock metamorphism features in the Sudbury Structure, Ontario, in J. V. Guy-Bray, ed., New developments in Sudbury Geology: Geological Association of Canada, 179-187.

Giblin, P. E., 1984, History of exploration and development of geological studies and development of geological concept, in E. G. Pye, A. J. Naldrett, and P. E. Giblin, eds., The geology and ore deposits of the Sudbury Structure: Ontario Geological Survey, $1,3-23$.

Grant, F. S., 1985, Aeromagnetic, geology and ore environments, 1: Magnetite in igneous, sedimentary and metamorphic rocks: An overview: Geoexploration, 23, 303-333, doi: 10.1016/0016-7142(85)90001-8.

Grant, R. W., and A. Bite, 1984, Sudbury quartz diorite offset dykes, in E. G. Pye, A. J. Naldrett, and P. E. Giblin, eds., The geology and ore deposits of the Sudbury Structure: Ontario Geological Survey, 1, 275-300.

Grauch, V. J. S., M. N. Hudson, and S. A. Minor, 2001, Aeromagnetic expression of faults that offset basin fill, Albuquerque basin, New Mexico: Geophysics, 66, 707-720, doi: 10.1190/1.1444961.

Heaman, L. M., 1997, U-Pb dating of dyke swarms: What are the options?: International Association of Volcanology and Chemistry of the Earth's Interior General Assembly, Continental Magmatism Abstracts, New Mexico Bureau of Mines and Mineral Resources, Bulletin 131, 125.

Hearst, R. B., and W. A. Morris, 2001, Regional gravity setting of the Sudbury Structure: Geophysics, 66, 16801690, doi: 10.1190/1.1487110.

Hood, P. J., 1965, Gradient measurements in aeromagnetic surveying: Geophysics, 30, 891-902, doi: 10.1190/1 .1439666 .

Hrouda, F., 1982, Magnetic anisotropy of rocks and its application in geology and geophysics: Geophysical Survey, 5, 37-82, doi: 10.1007/BF01450244.

Hsu, S. K., J. C. Sibuet, and C. T. Shyu, 1996, Highresolution detection of geologic boundaries from potential-field anomalies: An enhanced analytic signal 
technique: Geophysics, 61, 373-386, doi: 10.1190/1 1443966.

Krogh, T. E., D. W. Davis, and F. Corfu, 1984, Precise U-Pb zircon and baddeleyite ages for the Sudbury area, in E. G. Pye, A. J. Naldrett, and P. E. Giblin, eds., The geology and ore deposits of the Sudbury Structure: Ontario Geological Survey, 1, 431-446.

Krogh, T. E., S. L. Kamo, and B. F. Bohor, 1996, Shocked metamorphosed zircons with correlated U-Pb discordance and melt rocks with concordant protolith ages indicate an impact origin for the Sudbury Structure, in A. Basu, and S. Hart, eds., Earth processes: Reading the isotopic code: American Geophysical Union, 343-352.

L'Heureux, E., H. Ugalde, B. Milkereit, N. Eyles, J. Boyce, and W. Morris, 2003, Magnetic, gravity and seismic constraints on the nature of the Wanapitei Lake Impact Crater: Presented at 3rd International Conference on Large Meteorite Impacts.

Lochhead, D. R., 1955, The Falconbridge ore deposit, Canada: Economic Geology, 50, 42-50, doi: 10.2113/ gsecongeo.50.1.42.

Milkereit, B., and A. Green, and , Sudbury Working Group, 1992, Deep geometry of the Sudbury Structure from seismic reflection profiling: Geology, 20, 807-811, doi: $\quad$ 10.1130/0091-7613(1992)020<0807:DGOTSS $>2.3$ .CO;2.

Miller, H. G., and V. Singh, 1994, Potential field tilt — A new concept for location of potential field sources: Journal of Applied Geophysics, 32, 213-217.

Milligan, P. R., and P. J. Gunn, 1997, Enhancement and presentation of airborne geophysical data: AGSO Journal of Australian Geology \& Geophysics, 17, 63-75.

Minty, B. R. S., 1991, Simple micro-levelling for aeromagnetic data: Exploration Geophysics, 22, 591-592, doi: 10 .1071/EG991591.

Morris, W. A., 2002, The Sudbury Structure: A circular impact crater?: Geophysical Research Letters, 29, doi: 10 .1029/2002GL015255.

Naldrett, A. J., 1984, Summary, discussion and synthesis, in E. G. Pye, A. J. Naldrett, and P. E. Giblin, eds., The geology and ore deposits of the Sudbury Structure: Ontario Geological Survey, 1, 533-570.

Naldrett, A. J., R. H. Hewlins, B. O. Dressler, and B. V. Rao, 1984, The contact sublayer of the sudbury igneous complex: in E. G. Pye, A. J. Naldrett, and P. E. Giblin, eds., The geology and ore deposit: Ontario Geological Survey Special Volume, 1, 253-274.

Paakki, J. J., 1992, The Errington Zn-Cu-Pb massive deposit, Sudbury, Ontario: Its structural and stratigraphic setting and footwall alteration: Unpublished M.S. thesis, Laurentian University.

Peredery, W. V., and G. G. Morrison, 1984, Discussion of the origin of the Sudbury Structure: Ontario Department of Mines, Annual report for 1925, 34, 1-61.

Pilkington, M., and P. Keating, 2004, Contact mapping from gridded magnetic data - A comparison of techniques:
Exploration Geophysics, 35, 306-311, doi: 10.1071/ EG04306.

Pilkington, M., and P. Keating, 2010, Geologic applications of magnetic data and using enhancements for contact mapping: Presented at 2010 European Association of Geoscientists \& Engineers International Workshop.

Reeves, C. W., S. W. Reford, and P. R. Milligan, 1997, Airborne geophysics: Old methods, new images, in A. G. Gubins, ed., Proceedings of Exploration 97, 4th Decennial International Conference on Mineral Exploration, Prospectors and Developers Association of Canada, 13-30.

Riller, U., 2005, Structural characteristics of the Sudbury impact structure, Canada: Impact induced and orogenic deformation: Meteoritics and Planetary Science, 40, 1723-1740, doi: 10.1111/j.1945-5100.2005.tb00140.x.

Rousell, D. H., 1975, The origin of foliation and lineation in the Onaping Formation and the deformation of the Sudbury Basin: Canadian Journal of Earth Sciences, 12, 1379-1395.

Rousell, D. H., W. Meyer, and S. A. Prevec, 2002, Bedrock geology and mineral deposit, in D. H. Rousell, K. J. Jansons, and P. E. Giblin, eds., The physical environment of the City of Greater Sudbury: Ontario Geological Survey, 6, 21-55.

Shanks, W. S., and W. M. Schwerdtner, 1991, Structural analysis of the central and southwestern Sudbury Structure, Southern Province, Canadian Shield: Canadian Journal of Earth Sciences, 28, 411-430.

Smith, R. S., J. B. Thurston, T. Dai, and I. N. MacLeod, 1998, iSPI - The improved source parameter imaging method: Geophysical Prospecting, 46, 141-151.

Spector, A., and F. S. Grant, 1970, Statistical models for interpreting aeromagnetic data: Geophysics, 35, 293302, doi: 10.1190/1.1440092.

Thompson, J. E., 1957, Geology of the Sudbury basin: 65th Annual Report of the Ontario Department of Mines, 65.

Tschirhart, P., and W. A. Morris, 2012, Grenville age deformation of the Sudbury impact structure: Evidence from the magnetic modeling of the Sudbury diabase dyke swarm: Terra Nova, 24, 213-220, doi: 10.1111/j.13653121.2011.01056.x.

Verduzco, B., J. D. Fairhead, C. M. Green, and C. Mackenzie, 2004, New insights to magnetic derivatives for structural mapping: The Leading Edge, 23, 116-119, doi: 10.1190/1.1651454.

Watts, A., 1997, Exploring for nickel in the 90s, or 'til depth us do part', in A. G. Gubins, ed., Proceedings of Exploration 97: Fourth Decennial International Conference on Mineral Exploration, Prospectors and Developers Association of Canada, 1003-1014.

Wijns, C., C. Perez, and P. Kowalczyk, 2005, Theta map: Edge detection in magnetic data: Geophysics, 70, no. 4, L39-L43, doi: 10.1190/1.1988184. 
Wu, J., B. Milkereit, and D. Boerner, 1995, Seismic imaging of the enigmatic Sudbury Structure: Journal of Geophysical Research, 100, 4117-4130.

Young, G. M., D. G. F. Long, C. M. Fedo, and H. W. Nesbitt, 2001, Paleoproterozoic Huronian basin: Product of a Wilson cycle punctuated by glaciations and a meteorite impact: Sedimentary Geology, 141, 233-254.

Zolnai, A. I., R. A. Price, and H. Helmstaedt, 1984, Regional cross section of the Southern Province adjacent to
Lake Huron, Ontario: Implications for the tectonic significance of the Murray Fault Zone: Canadian Journal of Earth Sciences, 21, 447-456, doi: 10.1139/ e84-048.

Biographies and photos of the authors are not available. 